DOI: 10.15290/bsp.2017.22.01.en.05

\author{
Kinga Łuniewska \\ University of Białystok \\ kingapiwko@wp.pl
}

\title{
Disciplinary Liability of Legal Advisors and Legal Advisor Trainees in the Face of the Principle of a Fair Trial
}

\begin{abstract}
The legal advisory service is a liberal profession, a profession of public trust. The aim of this paper is to analyze the related disciplinary procedure and its specifics. The disciplinary liability of legal advisors regulates norms of conduct in a way that respects the rules of a fair trial. Full regulation of disciplinary responsibility is achievable through corporate law, in which reference is made to the Code of Criminal Procedure. Judicial authorities and self-governing bodies within the profession supervise the correct conduct of legal advisors. We also have to mention international law regulations whose standards of a fair trial are reflected in the Polish legislation.
\end{abstract}

Keywords: legal advisor, disciplinary liability, procedure, Act

A legal advisor is a liberal legal profession of public trust. According to some authors, "a purpose of strict principles of disciplinary liability - applicable to the professions of public trust respectively - is mainly focused on clients' interest"1. As far as the fulfilment of the above is concerned, provisions regulating disciplinary liability of the members of legal advisors' self-government are particularly important. According to a dictionary definition, responsibility is readiness to accept the consequences. Depending on a degree of subordination of an individual or some community (legal advisors' self-government) to the requirements of specific regulations, discipline may be higher, lower or none. A source of every discipline as well as the executor and source of sanctions are external factors ${ }^{2}$. Legal provisions are to guarantee an appropriate standard of client services and provide legal advisors and legal advisor trainees with an outlined nature of consequences connected with giving legal aid. Legal advisors and legal advisor trainees may be subject to different

1 H. Izdebski, P. Skuczyński (eds.), Etyka prawnicza: stanowiska i perspektywy, Warszawa 2013, p. 277.

2 S. Jedynak, Mały słownik etyczny, Bydgoszcz 1994, p. 52. 
systems of liability. The assessment of collected sources and materials on the basis of which this article has been written allows to formulate a thesis according to which Polish provisions exhaustively regulate disciplinary liability of legal advisors. Valid regulations embrace guidelines on including specificity of the profession of a legal advisor. The observance of legal advisors' rights is additionally guaranteed by the inclusion of criminal procedure principles in disciplinary proceedings and compliance with the principle of disciplinary liability's independence of other systems of liability. A purpose of the study is to analyze disciplinary proceedings including their specificity, establish the extent of disciplinary liability's independence of other possible systems of liability, and find out what mechanisms within these proceedings allow to observe the principles of a fair trial.

Fulfilling their official duties, legal advisors and legal advisor trainees are subject to legal provisions creating different bases of liability, namely: civil, criminal, corporate (professional) and disciplinary. The Act on Legal Advisors of 6 July 1982 (hereinafter referred to as the ALA) regulates a special nature of liability connected with the profession of a legal advisor or legal advisor trainee. A corporate regulation of disciplinary liability starts with the indication of offences activating this liability. Above all, the catalogue of acts is open and embraces an extremely wide range of all culpable acts undermining the profession's interest and dignity and resulting in its improper performance ${ }^{3}$. Art. 64 par. 1 of the ALA stipulates that legal advisors and legal advisor trainees are subject to disciplinary liability for culpable and improper performance of the legal advisor's profession as well as for acts contrary to the legal advisor's oath or principles of legal advisor's ethics. Since 2004, the above mentioned provision has distinguished disciplinary liability for a failure to conclude a mandatory insurance agreement - this obligation is applicable solely to legal advisors. Apart from positive prerequisites, the Act also indicates exclusions of disciplinary liability. Namely, it does not embrace acts breaching regulations on professional order and discipline covered by employee's corporate liability regulated in Art. 108 of the Employment Code and special Acts ${ }^{4}$.

Apart from indicating prerequisites of the liability, the above invoked provision of the ALA also denotes subjects disciplinary liability applies to. Respectively, a legal advisor and legal advisor trainee bear disciplinary liability after being entered into relevant lists - of legal advisors and legal advisor trainees. The Supreme Court's decision of 1 October 2004 SDI 7/40 confirms a group of entities subject to disciplinary liability and explains that "it is a natural effect of the assumption according to which corporate authorities such as Regional and Higher Disciplinary Tribunal cannot sentence in the case of subjects who are not members of the corporation. Hence

3 R. Tokarczyk, Etyka prawnicza, Warszawa 2007, p. 191.

4 Z. Klatka, Ustawa o radcach prawnych: komentarz, Warszawa 1999, p. 356 and n. 
a person crossed out from the list of legal advisors may not be held liable before the above mentioned corporate authorities of the legal advisors' self-government" .

Furthermore, a legal advisor bears liability for an act committed when he or she was entered in the list of legal advisor trainees ${ }^{6}$. The invoked opinion of Z. Klatka is supported by the valid case law, i.e. "when the accused person is already not a legal advisor trainee but a legal advisor, the catalogue of disciplinary penalties is not subject to any limitation. Then a choice of a penalty does not depend on the accused person's status at the moment of the act's commission because the moment of sentencing is decisive. The Act introduces only one exception - sentencing to disciplinary penalty is excluded in the form of the suspended right to practice a profession of a legal advisor if during sentencing the accused person is still a legal advisor trainee. Yet such a restriction is not envisaged if the accused person is already a legal advisor"7.

Significantly enough, disciplinary liability for undermining profession's dignity refers not only to conduct during official or public activity. An attitude of a legal advisor or legal advisor trainee in their private life is very important too ${ }^{8}$. A legal advisor may practice his or her profession within the framework of various contractual relations, that is on the basis of an employment agreement or in an employment relationship established on the basis of a unilateral act of a state body. Moreover, legal advisors and legal advisor trainees may pursue a business activity and provide legal services within this framework. Taking into account various forms of performed duties which are connected with a highly differentiated range of subordination, the scope of disciplinary liability is also distinct. The self-government itself undoubtedly plays the most important role in exercising custody over the performance of the profession in the form of private law firms. In other contractual relations, apart from the self-government, there is an additional supervisory authority - an employer or superior who may, for example, hold an employee liable for conduct inconsistent with mandatory provisions being in force in a given entity ${ }^{9}$. For this reason, Z. Klatka expressed his opinion about the form of practicing the profession and its importance for the nature of a liberal profession underlying that regardless of the form in which the profession is performed, it must always be free and independent ${ }^{10}$.

The principle of statutory definiteness, which is characteristic of criminal law, is of limited importance in disciplinary proceedings due to the lack of a closed catalogue

$5 \quad$ Lex No. 568870.

$6 \quad$ Z. Klatka, Ustawa..., op. cit., p. 356

7 Decision of the Supreme Court of 29 January 2013, SDI 38/12, Lex No. 1297721.

$8 \quad$ Z. Klatka, Ustawa..., op. cit., p. 357.

9 P. Przybysz, Prawo do sądu w sprawach dyscyplinarnych, „Państwo i Prawo” 1998, No. 8, p. 68.

10 Z. Klatka, Aktualne problemy etyki radców prawnych a struktura wolnych zawodów prawniczych, (in:) H. Izdebski, P. Skuczyński (eds.), Etyka prawnicza: stanowiska i perspektywy, Warszawa 2013, p. 96. 
of disciplinary offences ${ }^{11}$. Taking into account only generally outlined prerequisites of liability, their assessment is not always uniform. The judicature proposes certain clues saying, for example, that disciplinary proceedings "may assess legal advisor's conduct in performing a given professional activity, e.g. meeting deadlines and formal requirements or failure to attend court hearings"12. According to the case law, we may distinguish conduct that is subject to disciplinary liability depending on the factual state. For instance:

"Unreasonable conviction of the party's professional attorney about a motion for reasons to the judgment submitted in due time during time limits opened for the appeal resulting from Art. $369 \$ 2$ of the Code of Criminal Procedure (CCP) confirms a failure to maintain due diligence and care about the party’s interest (Art. $168 \$ 1$ of the CCP)"13.

"A legal advisor is subject to disciplinary liability for culpable failure to pay contributions for the legal advisors' self-government (Art. 64 par. 1 of the Act of 6 July 1982 on Legal Advisors - Journal of Laws No. 19, item 145). On the other hand, a legal advisor is not subject to the above liability for a failure to submit an employment questionnaire upon the request of a self-government body"14.

A legal advisor trainee bears liability for improper performance of his or her official duties and acts committed contrary to the legal advisor trainee's oath ${ }^{15}$. In the decision of 29 January 2013 the Supreme Court ruled that "The profession of a legal advisor, a legal advisor trainee is preparing to practice, is a profession of public trust; therefore legal advisor trainees are bound by the principles of professional ethics as well. Due to the above, it may be held that a legal advisor trainee should observe ethical and moral principles not only in connection with the performance of a legal advisor trainee's duties. This particularly refers to the sphere of a legal activity" ${ }^{\prime 6}$.

Minister of Justice plays an important role in disciplinary proceedings because he or she supervises the activity of the legal advisors' professional self-government within the scope and forms specified by the Act. Since 2007 Minister of Justice has additionally been entitled to order initiation of proceedings against a legal advisor or legal advisor trainee ${ }^{17}$. Moreover, Disciplinary Ombudsman serves Minister of Justice with the official copies of decisions on the initiation of proceedings, and informs him or her about submission of a motion to launch disciplinary proceedings in a disciplinary tribunal, or referral of a motion for punishment to the Dean of the Regional Council of Legal Advisors' Association. Minister of Justice has the right

11 P. Przybysz, Prawo do sądu..., op. cit., p. 68.

12 The Decision of the Supreme Court of 11 May 2009, I UZ 12/09, OSNP 2011/3-4/42.

13 Ibidem.

14 The Resolution of the Supreme Court of 26 April 1990, III PZP 2/90, OSNC1990/12/142.

15 Z. Klatka, Ustawa..., op. cit., p. 360.

16 The Decision of the Supreme Court of 29 January 2013, SDI 37/12, Lex No. 1297720.

17 Journal of Laws of 2010, No. 10, item 65, as amended [Dz.U. z $2010 \mathrm{Nr}$ 10, poz. 65 ze zm.]. 
to appeal against rulings terminating proceedings, access case files and request information about the results of disciplinary proceedings at every stage thereof. Moreover, Minister of Justice has the right to request final disciplinary rulings or decisions together with the attached case files to be handed over to him or her. Disciplinary Tribunal immediately sends the official copy of a final ruling to notify Minister of Justice.

Regulation of Minister of Justice on the Principles of a Course of Disciplinary Proceedings against Legal Advisors and Legal Advisor Trainees ${ }^{18}$ was in force for a relatively long time, i.e. from 1984 to 2007. At present, disciplinary proceedings are also carried out under the provisions of the Code of Criminal Procedure (hereinafter referred to as the $\mathrm{CCP})^{19}$. Due to the provision ordering appropriate application of the CCP, however, the procedure should include differences resulting from the Act on Legal Advisors. In cases not regulated in the Act on Legal Advisors, provisions on criminal procedure must be applied appropriately ${ }^{20}$. To be more precise, under and in connection with Art. 741 of the ALA, examining appeals against decisions of disciplinary ombudsmen on the refusal to initiate disciplinary proceedings or discontinue already launched proceedings, regional disciplinary tribunals should apply the provisions of the Code of Criminal Procedure, respectively, i.e. Art. 306 $\S 1$ of the CCP in connection with Art. 325a $\$ 2$ of the CCP, Art. 329 of the CCP, or Art. 521 of the $\mathrm{CCP}^{21}$. On the other hand, there is a decisive opinion of the Supreme Court ordering application of some provisions of the CCP directly. For example, according to the judgment of the Supreme Court of 25 July 2018, SDI12/13, "the provisions of Art. $433 \$ 2$ of the CCP and Art. $457 \$ 3$ of the CCP should be applied directly in disciplinary proceedings against legal advisors". The Court underlined that it is justified by the content of the quoted provisions, namely: "The first of the above provisions obliges the appellate court to consider all conclusions and charges indicated in the appeal whereas Art. $457 \$ 3$ of the CCP specifies the required content of the grounds to the appellate court's judgment stipulating that it should include the reasons for the court's judgment and explanations why the charges and conclusions of the appeal were found reasonable or unreasonable by the court"22. Furthermore,

18 Regulation of the Minister of Justice on the Procedure and Rules of Disciplinary Proceedings in Relation to Legal Advisers and Trainee Legal Advisers of April 6, 1984 (Journal of Laws of 1984, No. 27, item 138, as amended) [Rozporząazzenie Ministra Sprawiedliwości w sprawie trybu i zasad postępowania dyscyplinarnego $\mathrm{w}$ stosunku do radców prawnych i aplikantów radcowskich $\mathrm{z}$ dnia 6 kwietnia 1984 r., Dz.U. Nr 27, poz. 138].

19 W. Bujko, Postępowanie dyscyplinarne, (in:) A. Bereza (ed.), Zawód radcy prawnego. Historia zawodu i zasady jego wykonywania, Warszawa 2011, p. 239.

20 Art. 741 of the Act on Legal Advisors (Journal of Laws of 2010, item 133, as amended) [Ustawa o radcach prawnych (Dz.U. z 2010 r. Nr 10, poz. 65 ze zm.)]

21 W. Kozielewicz, Odpowiedzialność dyscyplinarna sędziów, prokuratorów, adwokatów, radców prawnych i notariuszy, Warszawa 2012, pp. 296-297.

22 The Judgment of the Supreme Court of 25 July 2013, SDI 12/13, Lex No. 1363207. 
in the part devoted to disciplinary liability of not only legal advisors, W. Kozielewicz specifies which Articles of the CCP are applied respectively in disciplinary proceedings and provides their list. What is more, the author indicates which CCP's regulations should absolutely be not applied in disciplinary cases ${ }^{23}$.

The repealed paragraph 2 of Art. 67 of the ALA set forth that initiation and pursuit of disciplinary proceedings depended on the circumstances excluding prosecution under the CCP. Since 2007, however, only paragraph 1 of Art. 67 of the ALA has been binding, which lays down optional suspension of proceedings until the end of criminal proceedings. The judicature points out that disciplinary proceedings should be suspended pending the outcome of criminal proceedings. Such an opinion is justified due to the functions of a criminal judgment, which may rebut the principle of assumed innocence. Two pursued proceedings may effect in an undesirable result, i.e. discrepant decisions on guilt. Nevertheless, according to the opposite opinion, which is coherent with the principle of separateness of disciplinary proceedings, pending criminal proceedings are not an obstacle justifying suspension of disciplinary proceedings under Art. $22 \$ 1$ of the $\mathrm{CCP}^{24}$.

There are also opinions saying that disciplinary proceedings may be re-instated through the application of criminal procedure provisions, however, "the application of the institution of re-opened proceedings regulated in the CCP due to the lack of any regulation thereof in the corporate Act is possible only if this necessity was a result of the need to assure a further course of the proceedings and to pass a decision. On the other hand, it is inadmissible to award the party with extraordinary rights aimed at the withdrawal of a final ruling"25.

Disciplinary proceedings are divided into three stages: investigation, proceedings before a disciplinary tribunal and enforcement proceedings ${ }^{26}$.

There are the following parties to disciplinary proceedings:

- Prosecutor - before Regional Disciplinary Tribunal it is Disciplinary Ombudsman, and before Higher Disciplinary Tribunal - Chief Disciplinary Ombudsman ;

- the accused - a legal advisor or legal advisor trainee against whom disciplinary proceedings have been launched. If the accused person dies before the end of disciplinary proceedings, they will be continued upon the request of his or her spouse, relatives in the direct line, or brother or sister within two months

23 W. Kozielewicz, Odpowiedzialność dyscyplinarna sędziów..., op. cit., pp. 71-72.

24 I. Bogucka, Odpowiedzialność dyscyplinarna, (in:) P. Skuczyński, S. Sykuna, Leksykon etyki prawniczej. 100 podstawowych pojęć, Warszawa 2013, p. 264.

25 The Decision of the Supreme Court of 15 November 2012, VI KZ 14/12, Lex No. 1228526.

26 Art. 671 of the Act of 6 July 1982 on the Legal Advisors (Dz.U. z 2010 r. Nr 10, poz. 65 ze zm.) [Journal of Laws of 2010, No. 10, item 65, as amended)]. 
from his or her death. The accused person may have a defence counsel, legal advisor or attorney;

- the injured party - a person whose legal interest has been directly infringed by the legal advisor or legal advisor trainee's conduct.

Article 70 of the ALA regulates limitation of penalty for disciplinary offences. Pursuant to this provision, disciplinary proceedings cannot be launched after the lapse of three years from the moment the act has been committed. With regard to the violation of the freedom of speech within legal limits and substantive need, the above time limit is shortened to six months. Significantly, punishment for a disciplinary offence is fully ceased after the lapse of five years from its commission while with regard to the violation of the freedom of speech under Art. 11 par. 2 of the ALA - after two years. We may come across opinions in the literature according to which limits of punishment are absolutely too short. Punishable persons may undertake activities aimed at a delay of disciplinary proceedings. For instance, such activities may involve a failure to pick up pleadings or inform about a new address of residence. On the other hand, invalid service entails a possibility of effective limitation of punishment. In result, effective avoidance of liability may entail that counting from the day on which the act has been committed, the required limitation of punishment will actually take effect ${ }^{27}$. Activities of Disciplinary Ombudsman or Chief Disciplinary Ombudsman undertaken in a given case interrupt running of limitation. A purpose of this regulation is to efficiently prevent avoidance of liability for committed offences. Pursuant to the Supreme Court's decision: "Limitation of a disciplinary offence specified in Art. 70 par. 1 point 2 of the Act of 6 July 1982 on Legal Advisors starts running on the day on which the Ombudsman learnt about the offence committed by a specific person first time"28. The above decision of the Court further indicates that serving the accused person with a decision on initiating investigative proceedings and bringing charges is an activity which interrupts the limitation period ${ }^{29}$. This may have a mobilizing impact on the resolution of disciplinary cases in a reasonable time.

The limitation of punishment of offences which concurrently satisfy the features of crimes regulated in the Criminal Code is either less likely or more difficult to achieve. Pursuant to Art. 70 par. 2 of the ALA, such offences are statute-barred after the lapse of time indicated in the Criminal Code.

Disciplinary liability envisaged in the ALA is a mechanism of care (custody) assuring a proper performance of the profession. It reflects the self-government's duty contained in Art. 17 of the Polish Constitution ${ }^{30}$. The Legal Advisors' Self-

27 W. Sarnowski, Postępowanie dyscyplinarne, "Radca Prawny" No. 4, 2004, p. 25.

28 The Decision of the Supreme Court of 24 October 2003, III DS 1/03, OSNP 2004/14/253.

29 Ibidem.

30 Z. Klatka, Aktualne problemy..., op. cit, p. 96. 
Government is composed of different bodies which must fulfil specific tasks. The authority competent to hear a case connected with a disciplinary offence is Regional Disciplinary Tribunal of the Regional Bar Association the accused person is a member of at the moment of launching disciplinary proceedings ${ }^{31}$. Article 702 par. 2 of the ALA specifies which authority is competent when the offence examined in one case has been committed by two or more perpetrators entered in the list of legal advisors or legal advisor trainees in different Associations. In the above described situation, a competent authority is Disciplinary Tribunal of the region where the offence has been committed. On the other hand, if the venue where the act has been committed cannot be established, a competent authority is Regional Disciplinary Tribunal of the region where disciplinary proceedings have been first initiated. Under circumstances not envisaged by the law whereby there is a dispute about the jurisdiction, Higher Disciplinary Tribunal is authorized to resolve this issue.

Disciplinary Tribunal is composed of legal advisors adjudicating in a collegiate body. Under the Constitution, which refers the notion of a court solely to authorities operating within the judicial power, disciplinary tribunals are not courts. For this reason, the principle of the right to a trial is fulfilled exclusively through the control exercised by state courts ${ }^{32}$. Disciplinary tribunals are qualified differently under Art. 6 of the Convention for the Protection of Human Rights and Fundamental Freedoms ${ }^{33}$. Considering the opinion held in the European Court of Human Rights' case law ${ }^{34}$, which is further depicted by, among others, M. Nowicki in the comments to Art. 6 of the Convention, a substantive meaning of the notion of a court itself is actually vital. Accordingly, the court fulfils a judicial function, i.e. it resolves cases within its jurisdiction in compliance with the rule of law in the proceedings carried out pursuant to the legally established procedure. In the meaning of the above mentioned legal base, the court should satisfy specific requirements ${ }^{35}$. One of them is autonomy (sovereignty). Lack of dependence on the executive power and the parties to the proceedings is guaranteed under Art. 73 of the ALA. In the light of the above quoted regulation, the court is solely subject to the Acts whereas the control of the validity of judgments is exclusively vested in another court - indicated directly in the corporate Act. On this basis, one may appeal against the judgment of a regional disciplinary tribunal to Higher Disciplinary Tribunal. The fact that disciplinary proceedings are carried out independent of criminal or other disciplinary proceedings whose results - similar to the rulings rendered by civil courts and administrative bodies - are not

Art. 702, par. 1 of the Act on the Legal Advisors (Journal of Laws of 2010, No. 10, item 65, as amended) [(Ustawa o radcach prawnych (Dz.U. z 2010 r. Nr 10, poz. 65 ze zm.)].

32 W. Bujko, Postępowanie dyscyplinarne..., op. cit., p. 242.

33 Journal of Laws of 2010, No. 90, item 587, as amended [Dz.U. z 2010 r. Nr 90, poz. 587 ze zm.]

34 The Judgment of ECHR of 29 April 1988 r.10328/83 Belilos v. Switzerland, Lex No. 81048.

35 M. Nowicki, Komentarz do art. 6 Konwencji o ochronie praw człowieka i podstawowych wolności, Lex, 2013. 
binding therein, emphasizes disciplinary proceedings' autonomy and independence of entities administering justice. The fact that disciplinary tribunals' members are not professional judges is not an obstacle in recognizing this authority as a court. Another condition is a sufficiently long term of office of this authority's members the term of office of disciplinary tribunals' members amounts to three years. They may fulfil their functions maximum for two consecutive terms of office. Next, courts should apply the procedure including guarantees appropriate for a given type of a case. Here, the corporate Act perfectly meets the above condition since the valid ALA's norms include specificity of a legal advisor's profession. The content of this Act contains substantive law prerequisites of disciplinary liability, bodies competent to hear cases and the most important principles of procedure applicable to a limited group of subjects, i.e. legal advisors and legal advisor trainees.

The European Court of Human Rights in Strasburg decided that in the meaning of Art. 6 par. 1 of the Convention, the notion of a court also covers disciplinary authorities such as professional bodies of liability ${ }^{36}$. The comments to Art. 6 of the Convention underline that members of a court may be persons who are not professional judges. Nevertheless, the court must be autonomous and impartial because a fair trial cannot be guaranteed without these features ${ }^{37}$. Furthermore, Art. 73 of the ALA secures autonomy and independence of entities administering justice because they are solely subject to the provisions of law with regard to sentencing.

The provisions on disciplinary liability of legal advisors reflect basic principles resulting from the criminal procedure (enshrined by the Constitution), i.e. two-tiered jurisdiction, openness and the right to defence ${ }^{38}$. An open nature of disciplinary proceedings is manifested in Art. 705 of the ALA, which stipulates that Minister of Justice and other persons authorized by him or her may access case files and request information about the results of disciplinary proceedings at every stage of the proceedings as well as request valid disciplinary rulings or decisions together with the attached case files. Moreover, an open and public nature of the proceedings is further expressed in Art. 703 of the ALA, pursuant to which judgments may only be rendered in a hearing.

The principle of two-tiered jurisdiction expressed in Art. 704 of the ALA implies that the parties and Minister of Justice are entitled to appeal against rulings and decisions terminating the proceedings within fourteen days from the day of serving the official copy of the ruling or decision together with the reasons and instructions on the course and term of appealing. This regulation is reflected in the case law. Namely, "a legal advisor whose sentence was suspended by the first instance

36 The Judgment of ECHR of 23 June 1981, Le Compte, Van Leuven and De Meyere A. 43, p. 23.

37 M. Nowicki, Komentarz do art. 6..., op. cit., Lex 2013.

38 A. Korzeniewska-Lasota, Zróżnicowanie modeli postępowania dyscyplinarnego, (in:) H. Izdebski, P. Skuczyński (eds.), Etyka prawnicza: stanowiska i perspektywy, Warszawa 2013, p. 129. 
disciplinary tribunal or who was deprived of the right to practice a profession has the right to appeal to the second instance disciplinary tribunal ; if such a penalty was imposed by the second instance disciplinary tribunal, the punished person has the right to appeal to the Supreme Court" 39 . The same opinion was held by the Supreme Court in the Resolution of Seven Judges of 20 July 1987, III PZP 25/87, and thus a legal principle was established ${ }^{40}$.

Disciplinary and criminal law belong to the same group of repressive law, which implies that their rules are common to all branches contained therein. With regard to the above, a closed catalogue of disciplinary penalties expresses the legislator's approval of the nullum crimen sine lege principle ${ }^{41}$. Art. 65 of the ALA enlists penalties that may be imposed for disciplinary offences. The most lenient one is admonition, to be followed by a slightly painful reprimand with a caution. Both penalties may be imposed both on a legal advisor and legal advisor trainee. Only a legal advisor may be punished by the suspension of the right to practice a profession from three months to five years. The next sanction is pecuniary penalty, which may not be lower than half average monthly salary in national economy for a month preceding the date of the ruling and not five times higher than this salary. The literature holds a reasonable opinion thereon, according to which the execution of this penalty may arise justified doubts as to the possibility of enforcing the imposed dues - their enforceability may be considerably impeded the same as the costs of disciplinary proceedings $\mathrm{s}^{42}$. It may be problematic due to a lack of a uniform and explicit regulation indicating according to which provisions the execution should be carried out. A valid legal status does not determine whether provisions on administrative execution should be applied or norms ensuing from the Code of Civil Procedure ${ }^{43}$.

Apart from a reprimand with a caution and pecuniary penalty, a legal advisor may be optionally punished by a patron ban from one to five years. A mandatory form of this ban amounts from two to ten years beside a penalty of a suspended right to practice a profession of a legal advisor ${ }^{44}$. The harshest penalty that may be imposed for a disciplinary offence is deprivation of the right to practice a profession of a legal advisor; in relation to legal advisor trainees - it is an expulsion from apprenticeship. The expulsion from apprenticeship entails crossing out of the list of trainees without the right to reapply for the entry to the list of legal advisor trainees or entry to the

39 The Decision of the Supreme Court of 7 September 1995, I PA 1/95, Lex No. 23564.

40 The Resolution of the High Court of 20 July 1987, III PZP 25/87, OSNC1988/5/54.

41 I. Bogucka, Odpowiedzialność..., op. cit., p. 254.

42 W. Sarnowski, Postępowanie dyscyplinarne..., op. cit., p. 26.

43 http://prawo.rp.pl/artykul/948825.html? print=tak\&p=0, (publication from 5 November 2012, consulted: 30 January 2017).

44 Art. 65 par. 2a and 2b of the Act of 6 July 1982 (Journal of Laws of 2010, No. 10, item 65, as amended) [Ustawa z dnia 6 lipca 1982 r. o radcach prawnych (Dz.U. z 2010 r. Nr 10, poz. 65 ze $\mathrm{zm})$.$] .$ 
list of legal advisors for ten years from the day on which the ruling became final and valid ${ }^{45}$. The regulation related to legal advisors was far more restrictive because crossing out of the list of legal advisors entailed a permanent ban on reapplying for another entry. The above invoked regulation was reflected in rulings. For instance: "A legal advisor shall lose a possibility of practicing his or her profession permanently as of the day on which a disciplinary tribunal's ruling depriving him or her of the right to practice this profession became final and valid. Crossing him or her out of the list of legal advisors is of merely formal nature and the punished person shall not practice the profession of a legal advisor until it is effected" 46 . However, shortly after the issue of the above quoted decision, point $2 \mathrm{c}$ of Art. 65 of the ALA was examined by the Constitutional Tribunal. In effect of the launched proceedings, the Constitutional Tribunal found the expression contained in the above mentioned provision "without the right to reapply for another entry" inconsistent with Art. 65 par. 1 in connection with Art. 31 par. 3 of the Constitution ${ }^{47}$.

The Act on Legal Advisors also envisages the occurrence of minor breaches in relation to which the above mentioned penalties would be too painful. For this reason, Art. 66 of the ALA vested Dean of Regional Council of Legal Advisors Association with legal power to punish for minor breaches. Pursuant to the above invoked provision, Dean is entitled to impose penal measures in the form of a warning which may be applied both against legal advisors and legal advisor trainees. These subjects have the right to appeal against Dean's warning. A competent body to hear the appeal is Regional Disciplinary Tribunal. On the other hand, a ruling issued in result of the appeal shall not be withdrawn ${ }^{48}$. A factual state and individualism of assessors may differentiate the situation of a person accused of a minor breach to a large degree. Thus the commentator's opinion thereon appears right. He draws attention to the fact that Dean's decision and his or her opinion on the assessment are not subject to control. That is why Dean should take into account a degree of the perpetrator's guilt, a burden of the breach and size of inflicted harm while deciding about the application of warning ${ }^{49}$.

It should be underlined here that a lack of statutory subordination of individual penalties to specific disciplinary torts provides disciplinary authorities with greater

45 Art. 65 par. 2d of the Act on Legal Advisors (Journal of Laws of 2010, No. 10, item 65, as amended) [Ustawa z dnia 6 lipca 1982 r. o radcach prawnych (Dz.U. z 2010 r. Nr 10, poz. 65 ze zm.)].

46 The Decision of the Supreme Administrative Court in Warsaw of 7 April 2010, II FSK 1929/08, http://www.orzeczenia-nsa.pl/postanowienie/ii-fsk-1929-08/egzekucja_swiadczen_pienieznych_ odrzucenie_skargi_kasacyjnej/178f6e7.html.

47 The Judgment of the Constitutional Tribunal of 18 October 2010, K 1/09, OTK s. A $2010 \mathrm{Nr}$ 8, item 76.

48 Art. 66 of the the Act of 6 July 1982 (Journal of Laws of 2010, No. 10, item 65, as amended) [Ustawa z dnia 6 lipca 1982 r. o radcach prawnych (Dz.U. z 2010 r. Nr 10, poz. 65 ze zm.)]. 
freedom while assessing any circumstances related to the act, perpetrator and their social context in order to assure that imposed penalty is adequate to the committed act. A type of imposed penalty should depend on a type of breach and its weight (burden), an extent of social harm of the act, a degree of the perpetrator's guilt as well as mitigating and incriminating circumstances. A disciplinary authority imposes penalty envisaged in the Act at its discretion. Punishment must be suitable on account of developing legal awareness of the professional environment and a socially protected role of the profession ${ }^{50}$. The judicature embraces court opinions indicating when punishment is not adequate to the committed offence. An example of the above is the decision of the Supreme Court of 14 January 1999, III SZ 3/98 implying that deprivation of the right to practice a profession of a legal advisor imposed for notorious failure to pay contributions for the Legal Advisors' Self-Government is grossly disproportionally severe. A key expression here seems to be the term "in the light of previous decisions" because in the court's opinion there are circumstances which decide about such and no other attitude ${ }^{51}$. However, the court may decide a contrario that imposing a given penalty is the most reasonable. For instance, appropriation of money to the client's detriment justifies deprivation of the right to practice a profession imposed on a legal advisor"52.

Disciplinary proceedings' nature is by all mean repressive towards the accused person because they must force him or her to perform their duties properly. Discipline in the professions of public trust fulfils a preventive function and protects citizens against unprofessional legal aid. The author believes that a guarantee function of disciplinary proceedings safeguards the accused person's main interest whose rights should be respected in the proceedings before a corporate self-government authority. Moreover, the assessors' objectivism, who practice the same professions as the accused, may positively affect adequate punishment. It is of fundamental importance due to the fact that disciplinary liability of legal advisors and legal advisor trainees is independent ${ }^{53}$ of other possible systems of liability. It is important that the provisions of the ALA do not exclude liability of a different type, which may lead to the concurrence of proceedings.

Legal advisors and legal advisor trainees may also be subject to corporate liability. Nevertheless, the fact that corporate disciplinary liability takes priority herein is of vital importance to protect legal advisor's independence. Pursuant to the Supreme Court's opinion: "One cannot be held corporately liable for the conduct that is "consistent with the order or ban, or authorization of the valid Act" even if such conduct formally infringed norms of professional ethics contained in the code

50 I. Bogucka, Odpowiedzialność..., op. cit., p. 260.

51 The Judgment of the Supreme Court of 14 January 1999, III SZ 3/98, Lex No. 1239054.

52 The Judgment of the Supreme Court of 24 September 1997, III SZ 2/97, Lex No. 33004.

53 Z. Klatka, Komentarz do ustawy..., op. cit., p. 355. 
of professional ethics adopted by a given professional corporation" ${ }^{34}$. In the above situation disciplinary liability before authorities of Legal Advisors' Self-Government takes precedence. Furthermore, the comments to Art. 67 of the ALA imply that a legal advisor practicing the profession on the basis of an employment relation may be subject to disciplinary liability envisaged in official service pragmatics regardless of corporate liability. The scopes of these two liabilities do not have to overlap. The author underlines that the ALA comprehensively regulates the performance of a legal advisor's profession in every legal form. Hence it should be held that it takes precedence before pragmatics of official service regulations. On the other hand, if there are no such regulations in the corporate Act, a legal advisor bears disciplinary liability according to the principles determined in the binding official service pragmatics ${ }^{55}$.

Legal advisors (the same as legal advisor trainees) may take civil liability ensuing from a contract and tort. Subordination to the above mentioned models of disciplinary liability does not collide with disciplinary liability regulated in the ALA at all. Even though the principles and sanctions are distinct, the same act may be subject to civil and disciplinary liability. Although the ALA's provisions do not envisage regulations connected with the need to suspend disciplinary proceedings for the duration of a civil case, a decision of a disciplinary tribunal finding the accused liable as charged may be used as evidence in a civil trial. Opposite to the corporate Act, the Code of Civil Procedure indicated in Art. $177 \$ 1$ point 4 an optional possibility of suspending civil proceedings "if criminal or disciplinary establishment of an act coming to light could affect the case's resolution" ${ }^{26}$.

Legal advisors and legal advisor trainees are held criminally liable for an act satisfying features of a crime envisaged in the Criminal Code. Under the ALA, legal advisors have been granted immunity exempting them from criminal liability for insult or defamation - Art. 11 par. 2 of the ALA. Even though criminal liability for the above mentioned offence has been excluded, it is still possible to enforce civil and disciplinary liability ${ }^{57}$. For the needs of this study, attention should also be paid to a possibility of holding a legal advisor liable for the violation of the Act on Counteracting Money Laundry and Financing Terrorism. Legal bases of the above liability are determined in the Criminal Code and Act on Counteracting Money Laundry and Financing Terrorism.

54 The Judgment of the Supreme Court of 27 Sepbember 2012 r. SDI 24/12.

55 Z. Klatka, Komentarz do ustawy..., op. cit., p. 369.

56 The Act of 17 Nobember 1964 - Code of Civil Procedure (consolidated text, Journal of Laws of 2016, item 1822, as amended) [Ustawa z dnia 17 listopada 1964 r. - Kodeks postępowania cywilnego, tekst jedn. Dz.U. z 2016 r. poz. 1822].

57 W. Bujko, Zawód radcy prawnego i samorząd zawodowy radców prawnych w orzecznictwie Trybunału Konstytucyjnego, (in:) A. Bereza (ed.), Zawód radcy prawnego. Historia zawodu i zasady jego wykonywania, Warszawa 2011, p. 282. 
Summing up, disciplinary liability of legal advisors and legal advisor trainees is regulated in compliance with the principles of a fair trial. Complete regulation of legal advisors and legal advisor trainees' disciplinary liability in the Polish legal system is provided by reference to the appropriate application of the provisions of the Code of Criminal Procedure contained in the corporate Act in relation to matters not regulated by it. The fulfilment of tasks assuring proper performance of the legal advisor's profession is safeguarded by the authorities of Legal Advisors' SelfGovernment and judicial bodies. We must also remember that Polish regulations reflect norms of international law on the standards of a fair trial.

\section{BIBLIOGRAPHY}

Bogucka I., Odpowiedzialność dyscyplinarna, (in:) P. Skuczyński, S. Sykuna (eds.), Leksykon etyki prawniczej. 100 podstawowych pojęć, Warszawa 2013.

Bujko W., Postępowanie dyscyplinarne, (in:) A. Bereza (ed.), Zawód radcy prawnego. Historia zawodu i zasady jego wykonywania, Warszawa 2011.

Izdebski H., Skuczyński P. (eds.), Etyka prawnicza: stanowiska i perspektywy, Warszawa 2013.

Jedynak S., Mały słownik etyczny, Bydgoszcz 1994.

Klatka Z., Ustawa o radcach prawnych: komentarz, Warszawa 1999.

Korzeniewska-Lasota A., Zróżnicowanie modeli postępowania dyscyplinarnego, (in:) H. Izdebski, P. Skuczyński (eds.), Etyka prawnicza: stanowiska i perspektywy, Warszawa 2013.

Kozielewicz W., Odpowiedzialność dyscyplinarna sędziów, prokuratorów, adwokatów, radców prawnych i notariuszy, Warszawa 2012.

Nowicki M., Komentarz do art. 6 Konwencji o ochronie praw człowieka i podstawowych wolności, Lex 2013.

Przybysz P., Prawo do sądu w sprawach dyscyplinarnych, “Państwo i Prawo” 1998, No. 8.

Sarnowski W., Postępowanie dyscyplinarne, “Radca Prawny” 2004, No. 4.

Tokarczyk R., Etyka prawnicza, Warszawa 2007. 